\title{
RECOMMENDATIONS FOR AN
}

INNOVATIVE GENDER-SENSITIVE

Training AND EDUCATION FOR

VARIOUS FRONTLINE RESPONDER

\section{GROUPS}

\section{BetTina Pfleiderer \& PAUlina JuszCZyK}

Westfalian Wilhelm-University Münster, Faculty of Medicine, Münster, Germany. E-mail: pfleide@wwu.de; paulina.juszczyk@wwu.de

Abstract Rigid gender roles and gender stereotypes can limit both women's and men's choices, opportunities and access to power and resources. While both sexes suffer from domestic violence, women are more likely to experience repeated and severe forms of abuse, including sexual violence. However, the concept of gender goes beyond numbers, and it is an important human factor that is not integrated sufficiently in existing training, risk assessment tools and procedures. Understanding the gendered nature of domestic violence, but nevertheless taking into account that both men and women can suffer from violence, or be perpetrators, enables front-line responders to develop services that are sensitive to the different needs of individuals affected by domestic violence (DV). This chapter introduces the principles of innovative gender-sensitive training and education for various front-line responder groups. This chapter explains the reasons for it and how the gender norms and perceptions identified in the IMPRODOVA research, which may have a negative impact on front-line responders' responses to DV, were addressed in all IMPRODOVA instruments and guidelines in teaching formats.

Keywords:

domestic violence, gender roles, gender, police, social work, health sector, training 


\section{Introduction}

This chapter addresses whether domestic violence is gender neutral as it affects people of all genders and sexualities, and whether gender is therefore irrelevant to frontline responders' prevention of and response to domestic violence. From the perspective of the IMPRODOVA project, we consider gender to be an important aspect of domestic violence that should not be ignored and should be part of trainings and education of various frontline responder groups.

\section{Background}

The perception and understanding of "sex" and "gender" in general, and their meaning in the context of domestic violence should be an integral component of trainings for frontline responders. In general, "sex" refers to the sum of biological factors that determine whether an individual is female, male and/or intersex, while "gender" refers to the sociocultural factors like social norms and expectations of behaviour and appearance of individuals in social contexts. For example, one "typical" assumption is that men are "naturally" more violent or driven by uncontrollable sexual urges (Jewkes, 2002; Barker \& Pulerwitz, 2008). "Sex" and "gender" aspects differ in relation to men and women and are influenced by intersecting factors like race, social class, and culture. Therefore, gender is socially constructed.

Rigid gender roles and stereotypes can limit both women's and men's choices, opportunities and access to power and resources. The unequal distribution of power and resources of men and women can result in gender inequality and gender-based violence (EIGE, 2018). Gender equality means in turn that women and men have equal conditions, treatment, and opportunities for realizing their full potential, human rights and dignity, and for contributing to (and benefiting from), economic, social, cultural, and political development. Gender equity ensures this process. Transforming gender roles through women's empowerment by raising awareness and increasing access to resources and promoting new models of masculinities which break the connection between masculinity and violence are ways to build more equal gender relations (UNWOMEN, 2015). 


\section{Sex and gender aspects regarding victims of domestic violence}

There is a difference in sexes regarding the prevalence of domestic violence with females clearly outnumbering males (UNODC, 2019; UNODC, 2019a). While both sexes suffer from domestic violence, women are more likely to experience repeated and severe forms of abuse, including sexual violence. In the European Union, $22 \%$ of women have experienced physical or sexual violence in an intimate relationship since the age of 15 (FRA, 2014) and about $43 \%$ of women have experienced psychological violence in an intimate partnership (FRA, 2014). Moreover, almost 50 $\%$ of all homicides against women take place in the domestic sphere (Corradi et al., 2018).

Domestic violence can lead to psychosocial and mental health problems with increased burden on women (Dekker et al., 2017). Since women often feel ashamed by victimisation and want to protect the family reputation or honour, female victims of domestic violence are more likely to stay in abusive relationships than men or do not report domestic violence to the police (Howarth \& Robinson, 2016).

There is a lack of representative data regarding the prevalence of domestic violence against men. Consequently, the number of men as victims of domestic violence is underestimated and support services for them are lacking (Barber, 2008; Ceelen, et al., 2013). Since domestic violence seems to be mostly associated with the female sex, there is an increased likelihood that frontline responders will overlook men as victims of domestic violence in intimate relationships. Due to the strong social stigma associated with being a male victim of domestic violence (DV), male victims seem to report incidents less often than female victims do (Pfleiderer \& Sondern, 2020). The most important reason for men affected by domestic violence not to report incidents is the belief that the police would not take any action (Ceelen, et al., 2013). In addition, it is less likely that it is reported by friends and family, because their perceptions are also gender-biased (Data Europa, 2016). In countries with more traditional gender norms and roles, such as Estonia, Latvia, Lithuania, Poland, Czech Republic, Hungary, Slovakia, Romania, Bulgaria etc. with a low Gender Equality Index score (EIGE, 2017), the perception of a man being the victim of domestic violence seems hardly imaginable. 


\section{Impact of sex and gender aspects regarding the perpetrators of domestic violence}

Gender aspects in domestic violence are often misunderstood as differences in prevalence of DV between sexes. However, the concept of gender goes beyond numbers, and it is an important human factor when focussing on perpetrators. In addition to gender roles accepted in a certain cultural environment (e.g., traditional beliefs that men have the given natural right to control women) gender inequality and gender inequity ${ }^{1}$ play an important role (Salter, 2014). In a patriarchal society where men have more power, more sense of entitlement, and (on average) more income than women, it is known that overwhelmingly more men are the perpetrators of domestic and intimate partner violence (92\%; Hester, 2013). Men see their partners' professional success as a reason for their violent behaviour. However, women can be perpetrators as well, they usually use verbal violence more often. In contrast, male perpetrators use more often physical violence - involving serious injury, rape and even death. Very often - through excuses and justifications based on social and cultural practices, male perpetrators deny their responsibility for violent acts (Anderson \& Umberson, 2001).

It is often assumed that women charged with domestic violence have a history of victimisation by their partner and much of their violence is understood as retaliatory and/or defensive (Downs et al., 2007). In addition, some professionals even believe that women are not capable of being the original perpetrator (Fitzroy, 2001). In contrast, male offenders are primarily seen as perpetrators because they are perceived as more aggressive due to their gender roles (e.g., Eagly \& Steffen, 1986). In fact, studies suggest that women are as violent as men are. In some conditions, women could be the aggressors even more frequently than their violent or nonviolent male partners (Archer, 2000; Johnson \& Kelly, 2008). It should be acknowledged that women, like men, are socialised within a hierarchical social order where they can learn that violence can be an appropriate individualised response to difficult or problematic situations (Fitzroy, 2001).

\footnotetext{
${ }^{1}$ Gender equality and gender equity are related terms but have different meanings. As gender equity refers to the "fairness of treatment for both women and men according to their respective needs" (UNESDOC, 2000), it serves as a means to reach gender equality.
} 


\section{Perpetrator programmes}

Most programmes for perpetrators of domestic violence are tailored to males, there are only a few aiming at female perpetrators (e.g., the Duluth model ${ }^{2}$ ). These programmes include in general cognitive-behavioural approaches to address the perpetrator's use of abuse in their relationships and education about the gendered inequalities in society. Prosecutors and courts can request perpetrators to take part in perpetrator programmes, as for instance is the case in Germany or the UK (Akoensi et al., 2013; Hamilton et al., 2013), but since those programmes exist primarily for men, female offenders are too often left behind. To represent the diversity of perpetrators, programmes should become more inclusive in their service provision in the future.

\section{Impact of sex and gender aspects in frontline response}

Every social interaction is influenced by gendered perceptions (Ridgeway \& SmithLovin, 1999), including the response to domestic violence (Anderson \& Umberson, 2001). Most frontline responders are aware that it makes a difference whether the victim is male or female and whether the frontline responder is male or female. The perception and assumptions about one's own and the other sex and gender are thus important. Sex, gender, own mindsets, and expectations may have an impact on how one speaks with women and with men (e.g., strong voice, holding eye contact). This can also influence how one assesses the risk, the aspects recognised as significant (e.g., who started the incident), and how one perceives the victim. Moreover, it also affects how one is perceived by the victim (male or female) and other frontline partners. For instance, a female police officer could be seen as less threatening by a female victim who may then more willingly share information (Pfleiderer $\&$ Sondern, 2020).

Gendered perceptions run the risk of re-victimising victims in communication through the interrogation style using derogative words and not considering the victim as an autonomous individual. This might be causing victims not to share all relevant information because they do not feel as being taken seriously. Gendered perceptions also carry the risk that frontline responders may not take victims'

2 https://www.theduluthmodel.org/ 
complaints seriously and may downplay the incident, which might end in an escalation of violence because the frontline responders do not intervene to end the violence. Finally, gendered perceptions can eventually lead to not asking about certain forms of domestic violence because it is not assumed that anyone can experience them (Pfleiderer \& Sondern, 2020).

Although gender is an obvious factor of frontline response, it is not integrated sufficiently in existing trainings, risk assessment tools and procedures.

\section{Integration of sex and gender aspects in trainings}

The awareness of sex and gender aspects, particularly gendered perceptions, and biases, in domestic violence is of major importance to frontline responders. Therefore, sex and gender aspects should be integrated in all risk assessment instruments and training materials. A deeper understanding of sex and gender aspects will help frontline responders differentiate between various types of DV more appropriately and become fully aware of the effects gendered perceptions and biases may have on their professional judgements. Frontline responders should be trained to reflect their own behaviour and judgement (Houtsonen, 2020).

Gender-sensitive communication between frontline responders and victims ensures that women and men are treated as persons of equal importance and dignity. Using gender-sensitive language can make it easier to see important differences between male and female victims' needs, challenge unconscious assumptions about gender roles in society, and make victims more comfortable with a disclosure (EIGE, 2019). Therefore, aspects of gender-sensitive communication should be included in all training on DV.

Pfleiderer \& Sondern (2020) recommend based on the IMPRODOVA research results that the following sex and gender aspects should be included in risk assessment tools, procedures, and trainings:

- As victims could be financially dependent on their partners and therefore do not present all information about violent incidents, the victim's financial situation and current work situation should be assessed independent on the sex of the victim. 
- The past sexual history of the victim (e.g., frequent change of sexual partners, the way a victim is dressed) should not influence the risk assessment of the frontline responders and therefore not be part in risk assessment tools.

- Frontline responders should be aware that victims have gendered perceptions and conceptions that may lead biased interpretations and might influence the information that are released by the victim.

- As victims have their own assumptions about frontline responders' genderbased attitudes, frontline responders have to reassure victims to share all information without a fear of being judged or moralised.

Based on these recommendations, gender norms and perceptions that were identified in the IMPRODOVA research were integrated in all IMPRODOVA instruments and guidelines. In particular, Module 1 on the IMPRODOVA training platform (www.training.improdova.eu/en) integrated gender aspects into the training for all three sectors. Besides the definitions of gender and gender-based violence, facts about gender-based violence in Europe are presented. The Istanbul Convention also plays an important role here and is discussed in more detail in Module 6 of the training platform. Various tasks were designed to motivate users to reflect on their own gender perceptions. With the help of these tasks, the gender expectations in society and the respective culture are to be questioned (e.g., how men and women are expected to behave, how they may express their emotions).

Finally, in gender-sensitive DV trainings, stereotypes should also be addressed, since too many still assume that the perpetrators of domestic violence are exclusively men, and the victims are women. It needs to be recognised that most perpetrators are men, yet male victims of domestic violence have been largely ignored. An understanding of the gendered nature of domestic violence, but nevertheless considering that both, men and women can suffer from violence, or be perpetrators, enables frontline responders to develop services which are sensitive to the different needs of individuals affected by domestic violence. Male and female victims have different needs, they require different services and service approaches. To ensure that everyone affected by domestic violence gets the help and support they need, intra- and interorganisational cooperation in cases of domestic violence is needed. 


\section{References}

Akoensi, T. D., Humphreys, D. K., Koehler, J. A., \& Lösel, F. (2013). Domestic violence perpetrator programs in Europe, Part II: A systematic review of the state of evidence. International Journal of Offender Therapy and Comparative Criminology, 57(10), 1206-1225. https://doi.org/10.1177/0306624X12468110

Anderson, K. L. \& Umberson, D. (2001). Gendering violence: Masculinity and power in men's accounts of domestic violence. Gender \& Society, 15(3), 358-380. https://doi.org/10.1177/089124301015003003

Archer, J. (2000). Sex differences in aggression between heterosexual partners: A meta-analytic review. Psychological Bulletin, 126(5), 651-680. https://doi.org/10.1037/0033-2909.126.5.651

Atkinson, C., Downs, W. R., \& Rindels, B. (2007). Women's use of physical and nonphysical selfdefense strategies during incidents of partner violence. Violence Against Women, 13(1), 28-45. https://doi.org/10.1177/1077801206294807

Barber, C. F. (2008). Domestic violence against men. Nursing Standard, 22(51), 35-39. https://journals.rcni.com/doi/abs/10.7748/ns2008.08.22.51.35.c6644

Barker, G. \& Pulerwitz, J. (2008). Measuring attitudes towards gender norms among young men in Brazil: development and psychometric evaluation of the GEM Scale. Men and Masculinities, 10(3), 322-338. https://doi.org/10.1177/1097184X06298778

Ceelen, M., Drijber, B. C., \& Reijnders, U. J. L. (2013). Male victims of domestic violence. Journal of Family Violence, (28), 173-178. https://doi.org/10.1007/s10896-012-9482-9

Corradi, C., Naudi, M. \& Weil, S. (2018). Femicide across Europe. Theory, research and prevention. (1st ed.). Policy Press.

https://library.oapen.org/bitstream/handle/20.500.12657/28243/9781447347163.pdf?seque nce $=1 \&$ is Allowed $=y$

Dekker, J. J., Goudriaan, A. E., Kikker, M. J., Kleinhesselink, M. D. \& Waal, M. (2017). Gender differences in characteristics of physical and sexual victimization in patients with dual diagnosis: A cross-sectional study. BMC Psychiatry, 17(270), 1-9. https://doi.org/10.1186/s12888-017-1413-0

Eagly, A. H. \& Steffen, V. J. (1986). Gender and aggressive behavior: A meta-analytic review of the social psychological literature. Psychological Bulletin, 100(3), 309-330. https://doi.org/10.1037/0033-2909.100.3.309

EIGE (2017). Gender Equality Index. https:// eige.europa.eu/gender-equality-index/2015/comparecountries/index/map

EIGE (2018). Let's put an end to gender based violence. https:/ / eige.europa.eu/publications/lets-put-endgender-based-violence

EIGE (2019). Toolkit on Gender-sensitive Communication. A resource for policymakers, legislators, media and anyone else with an interest in making their communication more inclusive. https:// eige.europa.eu/publications/toolkit-gender-sensitive-communication

Fitzroy, L. (2001). Violent women: questions for feminist theory, practice and policy. Critical Social Policy, 21(1), 7-34. https://doi.org/10.1177/026101830102100101

FRA. (2014). Violence against women: an EU-wide survey. Main results. https://fra.europa.eu/sites/default/files/fra_uploads/fra-2014-vaw-survey-main-resultsapr14_en.pdf

Hamilton, L., Koehler, J. A., \& Lösel, F. A. (2013). Domestic violence perpetrator programs in Europe, Part I: A survey of current practice. International Journal of Offender Therapy and Comparative Criminology, 57(10), 1189-1205. https://doi.org/10.1177/0306624X12469506

Hester, M. (2013). Who does what to whom? Gender and domestic violence perpetrators in English police records. European Journal of Criminology, 10(5), 623-637. https://doi.org/10.1177/1477370813479078 
Houtsonen, J. (2020). Policing Domestic Violence: Strategy, Competence, Training. European Law Enforcement Research Bulletin, (19), 135-151.

https://bulletin.cepol.europa.eu/index.php/bulletin/article/view/417/318

Howarth, E. \& Robinson, A. (2016). Responding effectively to women experiencing severe abuse: Identifying key components of a British advocacy intervention. Violence Against Women, 22(1), 41-63. https://doi.org/10.1177/1077801215597789

Jewkes, R. (2002). Intimate partner violence: Causes and prevention. Lancet, 359(9315), 1423-1429. https://doi.org/10.1016/S0140-6736(02)08357-5

Johnson, M. P. \& Kelly, J. B. (2008). Differentiation among types of intimate partner violence: Research update and implications for interventions. Family Court Review, 46(3), 476-499. https://doi.org/10.1111/j.1744-1617.2008.00215.x

Pfleiderer, B. \& Sondern, L. (2020). Why the integration of sex and gender aspects will improve Domestic Violence Risk Assessment. European Law Enforcement Research Bulletin, (20), 155-165. http://bulletin.cepol.europa.eu/index.php/bulletin/article/view/413

Ridgeway, C. L. \& Smith-Lovin, L. (1999). The gender system and interaction. Annual Review of Sociology, 25(1), 191-216. https://doi.org/10.1146/annurev.soc.25.1.191

Salter, M. (2014). Multi-perpetrator domestic violence. Trauma, Violence, \& Abuse, 15(2), 102-112. https://www.jstor.org/stable/26638339

Data Europa (2016). Special Eurobarometer 449 : Gender-based violence http://data.europa.eu/euodp/en/data/dataset/S2115_85_3_449_ENG

UNESDOC. (2000). Gender equality and equity: a summary review of UNESCO's accomplishments since the Fourth World Conference on Women, Beijing 1995. https://unesdoc.unesco.org/ark:/48223/pf0000121145

United Nations. (2021). Goal 5: Achieve gender equality and empower all women and girls. https://www.un.org/sustainabledevelopment/gender-equality/

UNODC: United Nations Office on Drugs and Crime. (2019). Global study on homicide. Gender-related killing of women and girls. https://www.unodc.org/documents/data-andanalysis/gsh/Booklet_5.pdf

UNODC: United Nations Office on Drugs and Crime. (2019a). Homicide kills far more people than armed conflict, says new UNODC study. https://www.unodc.org/unodc/en/frontpage/2019/July/homicide-kills-far-more-peoplethan-armed-conflict--says-new-unodc-study.html

UNWOMEN. (2015). A framework to underpin action to prevent violence against women. https://www.unwomen.org//media/headquarters/attachments/sections/library/publications/2015/prevention_framewo rk_unwomen_nov2015.pdf?la $=$ en\&vs $=5223$ 
